\title{
Cluster policies of large cities in Russia and Kazakhstan
}

\author{
I.D. Turgel ${ }^{1} \bowtie$, L.L. Bozhko ${ }^{2}$, V.T. Pandzhiyeva ${ }^{1}$ \\ ${ }^{1}$ Ural Federal University, Ekaterinburg, Russia; e-mail: turgel@k96.ru \\ ${ }^{2}$ Rudny Industrial Institute, Rudny, Kazakhstan
}

\section{KEYWORDS}

clusters, large cities, cluster policy, classification of clusters, Russia, Kazakhstan of urban economy. Questions dealing with cluster-based policies and cation of clusters operating on the regional and national levels have attracted much scholarly attention while there is still a research gap regarding urban cluster policies and comparison of city-based clusters. Research objective. The purpose of this study is to analyze the legal framework of cluster policies in Russia and Kazakhstan and to describe the criteria for classification and comparison of city-based clusters. Data and methods. The study used methods of systemic and comparative analysis, formalized methods of analysis of regulatory acts. The selected criteria are universal and can be used for cluster analysis in different countries. We considered strategies for socio-economic development of large cities in Russia and Kazakhstan from the official websites of city administrations as well as the regulatory acts of specific cities. Results. In both countries, clusters play a significant role in the development strategies of territories. The Russian and Kazakh governments take similar measures to support cluster initiatives. The regulatory legal acts of both countries emphasize the allocation of subsidies and co-financing of regional programs and R\&D in clusters. The process of cluster creation in Russia started later than in Kazakhstan but was also more intensive. A popular specialization for clusters in both countries is information technologies and communications, which corresponds to the goals set by the national governments. Conclusions. In both countries, the number of clusters in large cities is increasing annually. Typically, clusters have 11-50 participants. In both countries, there are clusters of different specialization. Strategies for socio-economic development serve as the main documents for devising cluster policies of cities. The practical significance of the study is that it proposes an approach to classification and comparison of clusters that can be used in further analysis and for identification of cluster policy priorities.

\section{FOR CITATION}

Turgel, I.D., Bozhko, L.L., \& Pandzhiyeva, V.T. (2020). Cluster policies of large cities in Russia and Kazakhstan. R-economy, 6(1), 28-39. doi: 10.15826/recon.2020.6.1.003

\section{Кластерная политика крупнейших городов (опыт России и Казахстана)}

\author{
И.Д. Тургель ${ }^{1} \bowtie$, Л.Л. Божко ${ }^{2}$, В.Т. Панджиева ${ }^{1}$ \\ ${ }^{1}$ Уральский федеральный университет, Екатеринбург, Россия; e-mail: turgel@k96.ru \\ ${ }^{2}$ Рудный индустриальный институт, Рудный, Казахстан
}

\section{АННОТАЦИЯ}

Актуальность. В современном мире, подверженном активным процессам глобализации, возрастает необходимость выявления конкурентных преимуществ городов. Одним из источников таких преимуществ является кластеризация городской экономики. При этом остается открытым вопрос классификации и сравнений кластеров, локализованных в разных городах и разных странах. Исходя из вышесказанного, актуальность исследования обуславливается необходимостью разработки системы критериев для классификации кластеров, позволяющей осуществлять межгородские и кросс-национальные сравнения. Цель исследования. Анализ нормативно-правового регулирования кластерной политики в крупнейших городах РФ и Республики Казахстан, предложение и апробация критериев для классификации кластеров, созданных в городах данного типа. Данные и методы. В исследовании использованы методы системного и сравнительного анализа, формализованные методы анализа нормативно-правовых (c) Turgel, I.D., Bozhko, L.L., Pandzhiyeva, V.T., 2020

\section{КЛЮЧЕВЫЕ СЛОВА}

кластеры, крупнейшие города, кластерная политика, классификация кластеров, Россия, Казахстан 
актов. Предложен и обоснован выбор перечня критериев для классификации кластеров. Новизна авторского подхода состоит в универсальности отобранных критериев, возможности их использования для анализа кластеров в различных странах. Информационную базу исследования составили стратегии социально-экономического развития крупнейших городов России и Казахстана, представленные на официальных сайтах городских администраций. Эмпирической основой анализа послужили результаты исследований, проведенных в рамках НИР «Совершенствование политики государственного регулирования ускоренной кластеризации индустриальных регионов», выполняемой по грантовому финансированию Министерства образования и науки Республики Казахстан. Результаты. В ходе исследования был проведен анализ нормативно-правовых актов, составляющих основу кластерной политики в РФ и Республике Казахстан; изучен спектр услуг, оказываемых региональными центрами кластерного развития; установлены критерии для классификации кластеров в крупнейших городах, проведена классификация кластеров крупнейших городов РФ и Казахстана по заданным критериям. Выводы. На примере России и Казахстана были апробированы критерии для классификации кластеров, созданных в крупнейших городах. Практическая значимость исследования заключается в разработке подхода, позволяющего провести анализ и сравнение кластеров, созданных в крупнейших городах разных стран. Полученные в ходе классификации результаты могут быть использованы для выявления приоритетов кластерной политики на территории города.

\section{ДЛЯ ЦИТИРОВАНИЯ}

Turgel, I.D., Bozhko, L.L., \& Pandzhiyeva, V.T. (2020).

Cluster policies of large cities in Russia and Kazakhstan. R-economy, 6(1), 28-39. doi: 10.15826/recon.2020.6.1.003

\section{Introduction}

Clusters are drivers of modern economic development. Regardless of their specialization, clusters affect the key parameters of socio-economic development of a territory such as employment, wages, the number of enterprises, their stability and development. It has now become particularly important to study the role of cluster policies in socio-economic development of large cities. Each of them is unique in its own way, in particular in the resources and technologies they use and their prospects for development. Therefore, it is important to establish a set of criteria applicable for classification and comparison of different city-based clusters, which, in its turn, would enable researchers to identify general trends in clustering and analyze the key priorities of cluster development.

From the perspective of cluster theory, the contribution of this study is that it proposes a set of criteria to classify clusters in large cities of various countries. Practically, this classification can be used to identify cluster policy priorities in a city.

The research goal is to analyze the legal regulation of cluster policies in large cities of Russia and Kazakhstan as well as to propose criteria for classifying clusters that emerge in these cities. This research goal includes the following objectives:

- to analyze legal acts that form the basis of cluster policy in the Russian Federation and the Republic of Kazakhstan;
- to propose criteria for classifying clusters in large cities;

- to classify clusters of large cities in Russia and Kazakhstan according to the specified criteria;

- to analyze the priorities of cluster development in urban development strategies.

\section{Theoretical background}

The existing body of literature on the problems of clusters and cluster policies in large cities can be divided into two groups. The first group is devoted to questions concerning the nature of clusters and cluster policy, the impact of clusters on regional economic development. L.S. Markov, V.B. Kurmashev, and A.Yu. Nizkovsky contend that 'cluster policy is used as a generic notion for various ways of supporting and creating network enterprises' [1]. M.S. Kokareva systematized the approaches of Russian and international scholars to defining the term 'cluster' and concluded that cluster is a 'spatial form of organization of productive forces, factors of production and social (economic and social) relations, which are characterized by the following features: geographical localization; specialization of manufacturing companies; diversity and plurality of participants, their interdependence and complementarity; competition and cooperation' [2]. H. Furre emphasizes the importance of clusters' influence on economy and, in connection with this, the need for a thorough study of the concept 'cluster policy' and its components. He defines cluster as 
a geographically close group of interconnected companies and associated institutions in a certain field, connected by common features and complementarity' [3]. 'Cluster policy' is understood here as any policy from the following three categories: policies aimed at creating, mobilizing, or strengthening a specific cluster; policies that use clusters to increase efficiency; and policies aimed at creating an optimal environment for development and creation of clusters [3].

S. Brakman and R. van Marrewijk identified a number of reasons why cluster policy is not always effective: the lack of an exact definition of the concept 'cluster'; difficulties in limiting a cluster in space; and the partial character of Porter's model [4].

L. Corrado, R. Martin, and M. Weeks propose a methodology to conduct endogenous selection of regional clusters using a multidimensional stationary criterion, where the number and composition of clusters are determined by applying pair wise criteria for regional differences in production output per head of the population in time [5].

Of particular interest is the study of Ye. Kozonogova [6], assessing the role of cluster policies in regional governments' problem-solving: improvement of the quality of life in the territory where the cluster is located; attracting investment; stimulation of small and medium-sized enterprises; development of international scientific and technical cooperation. As a result, she showed that clusters affect the level of wages in the territory. Moreover, as the number of clusters increases, there is also an increase in investment in fixed assets.

C. Ketels proves that cluster development is closely related to changes in regional development indicators. The most significant criteria affecting cluster policies include cluster location, its specialization, size, etc. [7].

E. DiMariaE and G. Costalonga discuss the general theoretical foundations of the cluster concept in economics and concepts of internationalization of business activity. Internationalization of clusters offers great opportunities for reorganization of regional innovative processes based on new forms of labor division and cooperation among cluster participants from around the world. Using the example of Italian industrial regions, the study shows that clusters open their borders through expansion of production and distribution chains both at the national and international levels. There are two main scenarios for the development of cluster internationalization: production and commercial [8].

Ye. Kutsenko and D. Meissner [9] analyze the impact of clustering on territorial development and emphasize that the application of the cluster approach makes innovation policies more comprehensive as they serve to coordinate the support of various participants and their efforts, thus linking the localized priority industries.

A separate group of studies is devoted to the problem of selecting criteria for classifying clusters. L. Bozhko emphasizes the importance of analysis of regulatory legal acts in studying cluster policies [10]. M.N. Nikonova [11] provides an analytical review of a modern package of documents, definitions, basic institutional factors and concepts that determine cluster policies in Russia. E.S. Kutsenko analyzes characteristics of a successful cluster: the quality of the urban environment; critical mass of core companies; dominance of private initiative; internal competition and openness; presence of specialized independent governing bodies and active working groups; formalization of rights, responsibilities and decision-making mechanisms; implementation of joint innovative projects and formation of a belt of innovative startups around large companies or universities. This study also focuses on the compliance of Russian pilot innovation clusters with the above-described characteristics and draws quantitative compraisons between Russian and foreign clusters [12].

Criteria for classification of clusters were identified by I. Rodionova, T. Kreidenko and C. Mandra [13]: territorial location of a cluster, specialization, number of participants, duration, year of creation, level of organization, and status. I.V. Mitrofanova, D.A. Sheikin, N.P. Ivanov and O.Yu. Trilitskaya [14] emphasize the importance of taking into account territorial location. Using correlation and regression analysis, dependence of the number of clusters in the territory on the number of commodity, financial and innovative markets is established. Identical criteria were selected for the comprehensive analysis of S.P. Zemtsov, P.N. Pavlov, A.V. Sorokina [15], who proposed a methodology for measuring cluster performance by the scale index, cluster development index, and its management efficiency index.

E.V. Kutsenko, E. Islankina, V. Abakshin [16] assess the impact of national cluster policy, cluster age, cluster development guidelines in neighboring regions and the cumulative level of regional 
innovation potential on the number and quality of cluster initiatives in Russia.

Other studies of cluster policies include those conducted by M. Delgado, M. Porter, S. Stern [17], K. Beshimbaeva [18], O.V. Kostenko [19], Ch. Karlsson [20], E.E. Kolchinskaya, L.E. Limonova, E.S. Stepanova [21], O.A. Vasilieva [22], E. Islankina [23], A.K. Akhmetova, D.M. Serikova, B.T. Sovetovich [24], J.S. Engel, I. del-Palacio [25].

Best practices of Russia and Kazakhstan in the field of regional cluster policy were explored by I.D. Turgel, L.L. Bozhko, and E.V. Pracheva [26].

Questions dealing with cluster-based policies and classification of clusters operating on the regional and national levels have attracted much scholarly attention while there is still a research gap regarding urban cluster policies and comparison of city-based clusters.

\section{Methods and data}

This study analyzes cluster policies and the corresponding legislation frameworks by focusing on clusters located in large, million-plus cities Almaty, Nur-Sultan and Shimkent in Kazakhstan and fourteen large cities in Russia (Moscow and St. Petersburg were not included in the sample, since their population is much bigger). The main sources of data were the socio-economic development strategies of these cities or, in the absence of an approved strategy, other similar documents; database 'Map of Russian Clusters' developed by specialists of the Russian HSE Cluster Observatory; and the official sites of clusters operating in large cities of Kazakhstan. Russia and Kazakhstan were chosen because these two countries have close political, economic and social ties.

In addition to the analysis of regulatory acts, the study examined information portals of the Russian Federation and the Republic of Kazakhstan devoted to cluster policy implementation. Particular attention was paid to the statistical data from the official portal of the project 'Map of Russian Clusters'.

The study includes four stages. At the first stage, we analyzed the main regulatory legal acts in the field of cluster policy in Russia and Kazakhstan. strategies for socio-economic development of territories, municipal programs, and other official documents. We also looked at the regulatory frameworks and government measures. At the second stage, universal criteria for classification and comparison of clusters in large cities were identified. At the third stage, clusters in large Rus- sian and Kazakh cities were classified and compared in accordance with the selected criteria. At the final stage, the study compares approaches that justify priorities of cluster development in the strategic plans of Russian and Kazakh cities. For clarity, the results are displayed in the form of graphs, charts, and tables.

\section{Results}

\section{Regulation of cluster policies in Russia and Kazakhstan}

Our analysis of the regulatory frameworks for cluster policies has brought to light the key areas of cluster development in both countries. In Russia, the regulatory framework comprises the Strategy for Innovative Development of the Russian Federation until 2020 and the Strategy for Spatial Socio-Economic Development of the Russian Federation until 2025. One of the 6 key objectives of the Strategy for Innovative Development of the Russian Federation until 2020 is associated with the development of clusters: intensification of activities to implement innovative policies in Russian regions and municipalities, formation of territories for innovative development, and development of innovative clusters.

The need for cluster development is also emphasized in the Strategy for Spatial Socio-Economic Development of the Russian Federation. According to the Strategy, innovation-related and social areas of the long-term socio-economic development of the Russian Federation include the following: formation of territorial production clusters (at least 6-8), focused on hightech industries in priority sectors of the economy, with a concentration of such clusters in urbanized regions; formation of territorial-production clusters in poorly developed territories, focused on the deep processing of raw materials and energy production using modern technologies'.

In Kazakhstan, the need to develop a coherent cluster policy was emphasized by President Nazarbayev in his Message to the People of Kazakhstan. In the strategy of 'Kazakhstan-2050', the President set the goal to design roadmaps for the formation of national clusters. The regulatory documents include the State Program for In-

\footnotetext{
Strategy for Spatial Socio-Economic Development of the Russian Federation. Retrieved from: https://economy.gov. $\underline{\mathrm{ru} / \mathrm{material} / \text { directions/regionalnoe razvitie/strategicheskoe }}$ planirovanie prostranstvennogo razvitiya/strategiya prostranstvennogo razvitiya rossiyskoy federacii na period do 2025 goda/
} 
dustrial and Innovative Development (SPIID) of the Republic of Kazakhstan for 2015-2019 and the project of the Government of the Republic of Kazakhstan and the World Bank - 'Improvement of Competitiveness of Small- and Medium-Sized Enterprises in Kazakhstan', which identified 6 pilot territorial clusters.

The normative legal act describing the main provisions of the cluster policy is the Concept of National Cluster Formation of the Republic of Kazakhstan until 2020. According to the Concept, the cluster policy has two main focus areas: national clusters in traditional sectors and clusters in the 'economy of the future'. This line is continued in the State Program of Industrial and Innovative Development of the Republic of Kazakhstan for 2020-2025, which describes the mechanism for stimulation of territorial cluster development.

In both countries, clusters play a significant role in the development strategies of territories. The measures the Russian and Kazakh governments take to support cluster initiatives are to a great extent identical. The regulatory legal acts of both countries emphasize the allocation of subsidies and co-financing of regional programs, financing of $\mathrm{R} \& \mathrm{D}$ in clusters. Considerable attention is paid to the need to establish relationships between the main stakeholders involved in the process of creating and maintaining clusters.

\section{Classification and comparative analysis of clusters in Russia and Kazakhstan}

The following criteria were selected for comparing clusters in large cities of Russia and Kazakhstan:

- year of the cluster's creation;

- number of participants;

- cluster specialization;

- the role of cluster policy, indicated in the strategy of socio-economic development of a territory

We classify the clusters of large Russian and Kazakh cities depending on the year of their creation (see Table 1).

Clusters in Russia started to be created later than in Kazakhstan and this process was also more intensive. In Kazakhstan, the first officially registered clusters appeared in 2005, but their creation went much slower (Figure 1).

The second criterion deals with the number of participants in clusters (see Table 2).

Figure 2 illustrates the distribution of million-plus cities in Russia by the number of partici- pants. Most Russian clusters are quite small. Clusters with most participants are located in Kazan (Kama Innovation Territorial-Production Cluster, Machine-Building Cluster), Novosibirsk (scientific and production cluster 'Siberian Naukopolis'), Ufa (Petrochemical Territorial Cluster of the Republic of Bashkortostan). There are 51-100 participants in the Innovative Territorial Cluster of Medical and Pharmaceutical Technologies of Samara Region as well as in the Information Technology Cluster (Kazan).

In Kazakhstan, distribution of clusters by the number of participants is more even (Figure 3). Like in Russian cities, most clusters have 1150 participants. Clusters with most participants (over 250) are concentrated in Almaty. The largest in terms of the number of participants is the Astana International Financial Center located in Nur-Sultan (387 participants).

Classification of clusters depending on their specialization is presented in the following table (see Table 3).

As the table above shows, in four Russian cities there are clusters specializing on IT technologies (Perm, Rostov-on-Don, Novosibirsk, Kazan) and in production of machinery and equipment (Chelyabinsk, Voronezh, Rostov-on-Don, Yekaterinburg). On the other hand, many clusters' specializations are found in one city only.

For the Russian government, the key priority tasks are to enhance economic performance and to stimulate innovation-based development. The intensive development of telecommunication industry is one of the main areas in this process. The national program 'Digital Economy of the Russian Federation' emphasizes the importance of IT cluster development, which means that such clusters are more likely to receive state support. As for the second type of specialization, production of machinery and equipment, its popularity largely stems from the availability of Soviet-period production facilities. The second reason is that many territories prioritize the development of production infrastructure.

In Kazakhstan, the most popular specializations for clusters are related to informatization and digitalization; IT technologies; smart industry; new materials; 'smart environment', etc. Like in Russia, the choice of clusters' specialization in Kazakhstan is largely determined by the priorities of the state. For instance, as a part of the state program 'Digital Kazakhstan', IT clusters are provided with state support. 
Table 1

Years of creation of the clusters in large cities of the Russian Federation and the Republic of Kazakhstan

\begin{tabular}{|c|c|c|}
\hline City & Cluster & $\begin{array}{c}\text { Year of } \\
\text { creation }\end{array}$ \\
\hline \multirow{6}{*}{ Kazan } & Kama innovation territorial-production cluster & 2012 \\
\hline & Engineering cluster & 2015 \\
\hline & IT Cluster & 2015 \\
\hline & Food cluster & 2016 \\
\hline & Innovative territorial cluster in the field of nanotechnology & 2014 \\
\hline & Territorial and industrial cluster AGROPOLIS 'ALKIAGROBIOPROM' & 2014 \\
\hline \multirow{2}{*}{ Yekaterinburg } & Innovative territorial cluster 'Titanium Cluster of Sverdlovsk Region' & 2012 \\
\hline & Cluster of lifting (crane) equipment & 2015 \\
\hline Novosibirsk & Scientific and production cluster 'Siberian Sciencepolis' & 2016 \\
\hline \multirow{9}{*}{ Rostov-on-Don } & Biotechnology (cluster for deep processing of grain in Millerovsky district of Rostov region) & 2015 \\
\hline & Wine-making territorial cluster 'Don Valley' & 2015 \\
\hline & Volgodonsk industrial cluster of nuclear engineering & 2016 \\
\hline & Innovative-territorial cluster of machine tools & 2015 \\
\hline & Innovation and technology cluster 'Southern Constellation' & 2015 \\
\hline & Innovative territorial cluster of civil marine instrumentation 'Marine Systems' & 2015 \\
\hline & Information and communications technology cluster (ICT cluster) of Rostov region & 2015 \\
\hline & Cluster for the production and processing of dairy products 'Don Dairy Products' & 2015 \\
\hline & Tourist area cluster & 2017 \\
\hline Ufa & Petrochemical territorial cluster of the Republic of Bashkortostan & 2012 \\
\hline \multirow{3}{*}{ Omsk } & Agro-biotechnological industrial cluster of Omsk region & 2016 \\
\hline & Cluster of high-tech components and systems of Omsk region & 2013 \\
\hline & Cluster of oil refining and petro chemistry of Omsk region & 2013 \\
\hline \multirow{5}{*}{ Voronezh } & Voronezh aviation cluster & 2014 \\
\hline & Cluster 'Voronezh Electromechanics' & 2010 \\
\hline & Cluster of manufacturers of oil and gas and chemical equipment in Voronezh region & 2016 \\
\hline & Furniture cluster of Voronezh region & 2013 \\
\hline & Radio-electronic cluster of Voronezh region & 2010 \\
\hline Nizhniy Novgorod & Nizhny Novgorod industrial innovation cluster in the field of automotive and petrochemicals & 2015 \\
\hline Chelyabinsk & Cluster of lifting (crane) equipment & 2015 \\
\hline \multirow{2}{*}{ Samara } & Innovative territorial aerospace cluster of Samara region & 2012 \\
\hline & Innovative territorial cluster of medical and pharmaceutical technologies of Samara region & 2014 \\
\hline Krasnoyarsk & Cluster of innovative technologies ZATO in Zheleznogorsk & 2011 \\
\hline \multirow{3}{*}{ Perm } & Innovative territorial cluster Technopolis 'Novyi Zvyozdnyi' & 2012 \\
\hline & Innovative territorial cluster of fiber-optic technologies 'Photonics' & 2014 \\
\hline & Perm cluster of information and communication enterprises & 2013 \\
\hline Krasnodar & 'Farm Valley' & 2017 \\
\hline \multirow[t]{2}{*}{ Volgograd } & $\begin{array}{l}\text { Innovative territorial cluster for the production of modern building materials and high-pu- } \\
\text { rity chemical products based on Svetloyarsky and Narimanovsky magnesium chloride } \\
\text { deposits in Volgograd region }\end{array}$ & 2013 \\
\hline & Chemical-pharmaceutical cluster in Volgograd region & 2012 \\
\hline \multirow{3}{*}{ Nur-Sultan } & Innovation cluster of Nazarbayev University & 2017 \\
\hline & International financial center 'Astana' & 2015 \\
\hline & High-tech industrial cluster & 2016 \\
\hline \multirow{2}{*}{ Almaty } & Innovation cluster 'Park of Innovative Technologies' & 2014 \\
\hline & Tourism development cluster & 2016 \\
\hline \multirow{4}{*}{ Shymket } & Pharmaceutical cluster & 2015 \\
\hline & Construction industry cluster & 2005 \\
\hline & Cotton-textile cluster of SEZ 'Ontustik' & 2005 \\
\hline & Petrochemical cluster SEZ 'Ontustik' & 2017 \\
\hline
\end{tabular}

Source: compiled based on the data of the Institute for Statistical Studies and Economics of Knowledge. Russian Cluster Observatory. Map of Russian Clusters. Retrieved from: http://map.cluster.hse.ru/list and the data of Kazakhstan Center for Industry and Export. Retrieved from: https://qazindustry.gov.kz/ru/analytics regions (Accessed: 25.02.2020). 
The number of participants in the clusters of large cities of Russia and Kazakhstan

\begin{tabular}{|c|c|c|}
\hline City & Cluster & $\begin{array}{l}\text { Number of } \\
\text { participants }\end{array}$ \\
\hline \multirow{6}{*}{ Kazan } & Kama innovation territorial-production cluster & 213 \\
\hline & Engineering cluster & 157 \\
\hline & IT Cluster & 70 \\
\hline & Food cluster & 20 \\
\hline & Innovative territorial cluster in the field of nanotechnology & 12 \\
\hline & Territorial and industrial cluster AGROPOLIS 'ALKIAGROBIOPROM' & 33 \\
\hline \multirow{2}{*}{ Yekaterinburg } & Innovative territorial cluster 'Titanium cluster of Sverdlovsk region' & 20 \\
\hline & Cluster of lifting (crane) equipment & 10 \\
\hline Novosibirsk & Scientific and production cluster 'Siberian Sciencepolis' & 227 \\
\hline \multirow{9}{*}{ Rostov-on-Don } & Biotechnology (cluster for deep processing of grain in Millerovsky district of Rostov Oblast) & 10 \\
\hline & Wine-making territorial cluster 'Don Valley' & 10 \\
\hline & Volgodonsk industrial cluster of nuclear engineering & 17 \\
\hline & Innovative-territorial cluster of machine tools & 13 \\
\hline & Innovation and technology cluster 'Southern Constellation' & 23 \\
\hline & Innovative territorial cluster of civil marine instrumentation 'Marine Systems' & 10 \\
\hline & Information and communications technology cluster (ICT cluster) of Rostov region & 25 \\
\hline & Cluster for the production and processing of dairy products 'Don Dairy Products' & 20 \\
\hline & Tourist area cluster & 10 \\
\hline Ufa & Petrochemical territorial cluster of the Republic of Bashkortostan & 211 \\
\hline \multirow{3}{*}{ Omsk } & Agro-biotechnological industrial cluster of Omsk region & 18 \\
\hline & Cluster of high-tech components and systems of Omsk region & 10 \\
\hline & Cluster of oil refining and petro chemistry of Omsk region & 14 \\
\hline \multirow{5}{*}{ Voronezh } & Voronezh Aviation Cluster & 10 \\
\hline & Cluster 'Voronezh Electromechanics' & 20 \\
\hline & Cluster of manufacturers of oil and gas and chemical equipment in Voronezh region & 16 \\
\hline & Furniture cluster of Voronezh region & 13 \\
\hline & Radio-electronic cluster of Voronezh region & 16 \\
\hline Nizhniy Novgorod & Nizhny Novgorod industrial innovation cluster in the field of automotive and petrochemicals & 33 \\
\hline Chelyabinsk & Cluster of lifting (crane) equipment & 10 \\
\hline \multirow{2}{*}{ Samara } & Innovative territorial aerospace cluster of Samara region & 13 \\
\hline & Innovative territorial cluster of medical and pharmaceutical technologies of Samara region & 55 \\
\hline Krasnoyarsk & Cluster of innovative technologies ZATO in Zheleznogorsk & 10 \\
\hline \multirow{3}{*}{ Perm } & Innovative territorial cluster Technopolis 'Novyi Zvyozdnyi' & 44 \\
\hline & Innovative territorial cluster of fiber-optic technologies «Photonics» & 34 \\
\hline & Perm cluster of information and communication enterprises & 10 \\
\hline Krasnodar & 'Farm Valley' & 15 \\
\hline \multirow[t]{2}{*}{ Volgograd } & $\begin{array}{l}\text { Innovative territorial cluster for the production of modern building materials and } \\
\text { high-purity chemical products based on Svetloyarsky and Narimanovsky magnesium } \\
\text { chloride deposits in Volgograd region }\end{array}$ & 10 \\
\hline & Chemical-pharmaceutical cluster in Volgograd region & 10 \\
\hline \multirow{3}{*}{ Nur-Sultan } & Innovation Cluster of Nazarbayev University & 20 \\
\hline & International financial center «Astana» & 387 \\
\hline & High-tech industrial cluster & 40 \\
\hline \multirow{2}{*}{ Almaty } & Innovation cluster 'Park of Innovative Technologies' & 285 \\
\hline & Tourism development cluster & 267 \\
\hline \multirow{4}{*}{ Shymket } & Pharmaceutical Cluster & 7 \\
\hline & Construction Industry Cluster & 20 \\
\hline & Cotton-textile cluster of SEZ 'Ontustik' & 13 \\
\hline & Petrochemical cluster SEZ 'Ontustik' & 9 \\
\hline
\end{tabular}

Source: compiled based on the data of the Institute for Statistical Studies and Economics of Knowledge. Russian Cluster Observatory. Map of Russian Clusters. Retrieved from: http://map.cluster.hse.ru/list and based on the data of Kazakhstan Center for Industry and Export. Retrieved from: https://qazindustry.gov.kz/ru/analytics regions (Accessed: 25.02.2020). 
Clusters' specialization in large Russian and Kazakh cities

Table 3

\begin{tabular}{|c|c|c|}
\hline City & $\begin{array}{c}\text { Number } \\
\text { of clusters }\end{array}$ & Specialization \\
\hline \multirow{6}{*}{ Kazan } & \multirow{6}{*}{6} & Automobile and automotive components manufacturing \\
\hline & & Automobile and automotive components manufacturing \\
\hline & & ICT \\
\hline & & Food and beverage production, tobacco products \\
\hline & & New materials \\
\hline & & Environmental protection and waste recycling \\
\hline \multirow[b]{2}{*}{ Yekaterinburg } & \multirow[b]{2}{*}{2} & Metallurgy, metal working and ready-made metal goods production \\
\hline & & $\begin{array}{l}\text { Production of machinery and equipment (including machining facilities, special equip- } \\
\text { ment, lifting and hydro pneumatic equipment, robots) }\end{array}$ \\
\hline Novosibirsk & 1 & ICT \\
\hline \multirow{9}{*}{ Rostov-on-Don } & \multirow{9}{*}{9} & $\begin{array}{l}\text { Industrial biotechnology (production of products based on enzymes and microorganisms } \\
\text { for further use in chemical industry, healthcare, food and forage production, detergents, } \\
\text { paper and pulp, textiles, bio energy) }\end{array}$ \\
\hline & & Food and beverage production, tobacco products \\
\hline & & Nuclear and radiation technologies \\
\hline & & $\begin{array}{l}\text { Production of machinery and equipment (including machining facilities, special equip- } \\
\text { ment, lifting and hydro pneumatic equipment, robots) }\end{array}$ \\
\hline & & Microelectronics and instrumentation \\
\hline & & Microelectronics and instrumentation \\
\hline & & ICT \\
\hline & & Agriculture and fisheries \\
\hline & & Tourism (entertainment and leisure industry, art, sports) \\
\hline Ufa & 1 & Chemical industry \\
\hline \multirow{3}{*}{ Omsk } & \multirow{3}{*}{3} & $\begin{array}{l}\text { Industrial biotechnology (production of products based on enzymes and microorganisms } \\
\text { for further use in chemical industry, healthcare, food and forage production, detergents, } \\
\text { paper and pulp, textiles, bio energy) }\end{array}$ \\
\hline & & Defense industry \\
\hline & & Chemical industry \\
\hline \multirow{5}{*}{ Voronezh } & \multirow{5}{*}{5} & Aircraft industry \\
\hline & & Microelectronics and instrumentation \\
\hline & & $\begin{array}{l}\text { Production of machinery and equipment (including machining facilities, special equip- } \\
\text { ment, lifting and hydro pneumatic equipment, robots) }\end{array}$ \\
\hline & & Furniture manufacturing \\
\hline & & Defense industry \\
\hline Nizhniy Novgorod & 1 & Automobile and automotive components manufacturing \\
\hline Chelyabinsk & 1 & $\begin{array}{l}\text { Production of machinery and equipment (including machining facilities, special equip- } \\
\text { ment, lifting and hydro pneumatic equipment, robots) }\end{array}$ \\
\hline \multirow{2}{*}{ Samara } & \multirow{2}{*}{2} & Space industry \\
\hline & & Medical industry \\
\hline Krasnoyarsk & 1 & Nuclear and radiation technologies \\
\hline \multirow{3}{*}{ Perm } & \multirow{3}{*}{3} & Space industry \\
\hline & & Optics and photonics \\
\hline & & ICT \\
\hline Krasnodar & 1 & Pharmaceuticals \\
\hline \multirow[t]{2}{*}{ Volgograd } & \multirow[t]{2}{*}{2} & $\begin{array}{l}\text { Production of building materials and other products from glass, concrete, cement, gypsum, } \\
\text { clay, ceramics and porcelain }\end{array}$ \\
\hline & & Medical industry \\
\hline \multirow{3}{*}{ Nur-Sultan } & \multirow{3}{*}{3} & $\begin{array}{l}\text { Information and Communication Technologies, Internet of Things (IOT), Big Data Analysis, } \\
\text { information security, artificial intelligence, machine learning, industrial automation, healthcare } \\
\text { and medicine, agricultural technologies, technologies in construction sector, energy efficiency }\end{array}$ \\
\hline & & $\begin{array}{l}\text { Brokerage activity, asset management, cash management, banking, Islamic finance, insur- } \\
\text { ance, financial technology, green technology }\end{array}$ \\
\hline & & Engineering, pharmaceuticals, food and chemical industries, building materials and logistics \\
\hline \multirow[t]{2}{*}{ Almaty } & \multirow[t]{2}{*}{2} & $\begin{array}{l}\text { Smart industry and new materials, new energy and clean technologies, smart environment, } \\
\text { fin tech, e-commerce and new media }\end{array}$ \\
\hline & & Tourism (entertainment and leisure industry, art, sports) \\
\hline
\end{tabular}


End of Table 3

\begin{tabular}{|l|l|l|}
\hline City & $\begin{array}{c}\text { Number } \\
\text { of clusters }\end{array}$ & \\
\hline \multirow{3}{*}{ Shymket } & \multirow{3}{*}{4} & Pharmaceuticals \\
\cline { 3 - 3 } & & Construction \\
\cline { 3 - 3 } & & Light industry \\
\cline { 2 - 3 } & & Chemistry, petro-chemistry \\
\hline
\end{tabular}

Source: compiled on the basis of the data of the Institute for Statistical Studies and Economics of Knowledge. Russian Cluster Observatory. Map of Russian Clusters. Retrieved from: http://map.cluster.hse.ru/list and the data of the Kazakhstan Center for Industry and Export. Retrieved from: https://qazindustry.gov.kz/ru/analytics regions (Accessed: 25.02.2020).

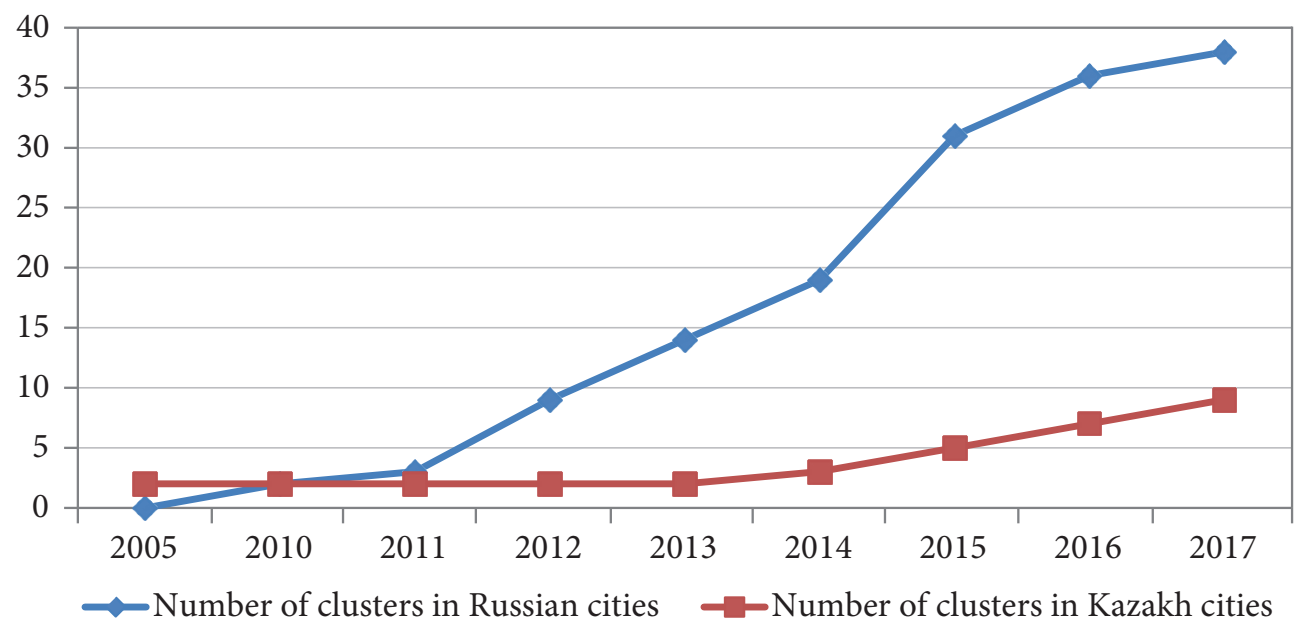

Figure 1. Dynamics of the number of clusters in large cities of Russia and Kazakhstan

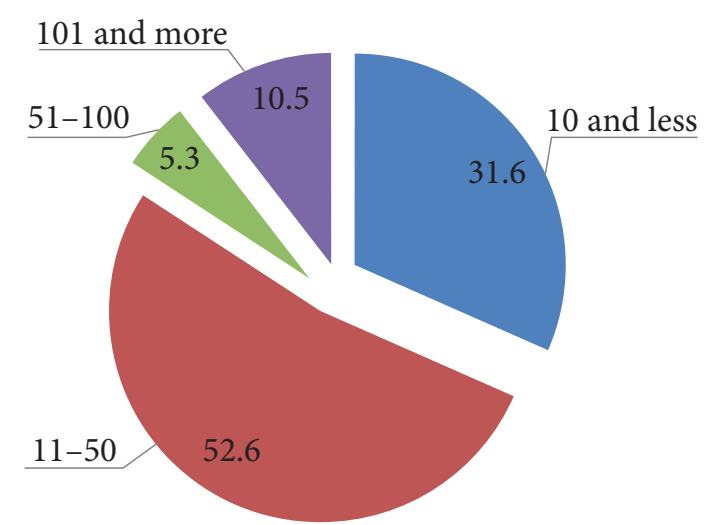

Figure 2. Number of participants in clusters of million-plus Russian cities, \%

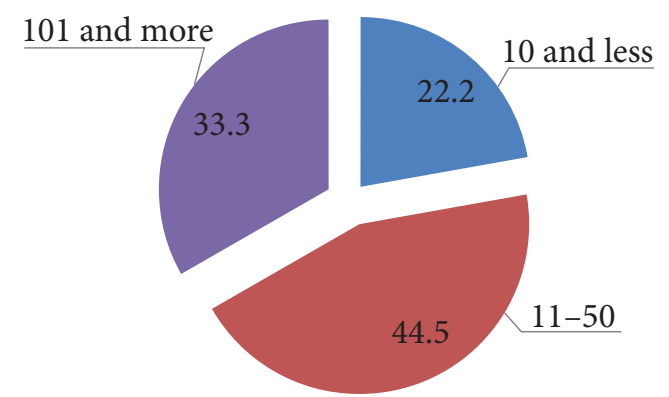

Figure 3. Number of participants in clusters of Kazakh cities, \%
Comparing clusters in Russia and Kazakhstan, it can be noted that in both countries, in one municipality there may be located clusters of various specializations. This is due, in particular, to an increase in diversity of network leaders: in addition to regional authorities and businesses, this role may be played by universities and R\&D organizations. 'Clusters arise naturally in places where there is a 'related diversity' of agents of economic activity, resources and components necessary for it. An important factor is 'cooperation and rivalry': participants of clusters do not only cooperate but also compete fiercely - for people, talents and customers. Finally, the proximity of clusters plays an important role ${ }^{2}$.

\section{Cluster policy priorities of large cities}

Most of the cities we discussed above seek to consolidate the cluster policy priorities and strategic urban development plans (see Table 4).

It is worth noting that not all urban strategies mention a cluster policy (for example, strategies of socio-economic development of Ufa, Omsk, Chelyabinsk, and Nizhniy Novgorod).

${ }^{2}$ Cluster approach: why some regions are more successful than others. Retrieved from: https://cluster.hse.ru/ news/341473882.html (Accessed: 27.02.2020) 
Cluster policy priorities in accordance with the strategy of socio-economic development

Table 4 of large Russian and Kazakh cities

\begin{tabular}{|c|c|}
\hline City & Cluster policy priorities \\
\hline \multirow{4}{*}{ Kazan } & Formation of 'smart economy' clusters \\
\hline & Technical re-equipment of production facilities for the clusters being formed \\
\hline & $\begin{array}{l}\text { Assistance in creative campus clusters creating, co-working for innovative and creative entrepreneurship, } \\
\text { attracting international partners }\end{array}$ \\
\hline & Promoting the effective interaction of business, science and government in clusters \\
\hline Yekaterinburg & 'IT-cluster' as a project within the framework of strategic programme 'Digital Yekaterinburg' \\
\hline \multirow{2}{*}{ Novosibirsk } & Development of scientific and industrial clusters as one of the opportunities for novosibirsk development \\
\hline & Development of an information cluster as one of the ways to develop digital economy \\
\hline \multirow{3}{*}{ Rostov-on-Don } & Revitalization and expansion of the cluster policy in key areas of industry \\
\hline & Launch of cluster projects in the fields of engineering, food industry and digital media communications \\
\hline & $\begin{array}{l}\text { Participation in the development of the existing and creation of new cluster interactions for information } \\
\text { and communication infrastructure development }\end{array}$ \\
\hline \multirow{3}{*}{ Voronezh } & $\begin{array}{l}\text { Creating conditions for activation of the city's universities: creation of technology parks, clusters, and } \\
\text { other forms of integrative interaction }\end{array}$ \\
\hline & Activation of the cluster policy in industry \\
\hline & Formation of scientific-educational and scientific-production clusters in high-tech se \\
\hline \multirow[t]{2}{*}{ Samara } & $\begin{array}{l}\text { Planning of further development of product-related, technological and managerial elements of manufac- } \\
\text { turing industries and clusters as a goal of innovative technological production }\end{array}$ \\
\hline & Development of tourism and aerospace clusters \\
\hline \multirow{3}{*}{ Krasnoyarsk } & Ensuring $\mathrm{t}$ \\
\hline & Creation of conditions for the development of high-tech competitive economic clusters \\
\hline & Creation of conditions for the formation and development of a medical cluster \\
\hline Perm & $\begin{array}{l}\text { Ensuring coordination of plans and programs for the city's development, including formation of clus- } \\
\text { ters to assist the city's enterprises in obtaining resources for modernization and development as one of } \\
\text { the key tasks of the functional and targeted programme of 'economic development' }\end{array}$ \\
\hline Krasnodar & $\begin{array}{l}\text { Development of a cluster of 'creative industries', financial cluster, transport and logistics cluster, industrial } \\
\text { construction cluster, agro-scientific cluster, tourism cluster, educational and scientific cluster, 'olympic' cluster }\end{array}$ \\
\hline \multirow{2}{*}{ Volgograd } & $\begin{array}{l}\text { Formation of a transport and logistics cluster as one of the goals of the transport and logistics complex } \\
\text { development }\end{array}$ \\
\hline & $\begin{array}{l}\text { Creating an enabling environment for tourism industry, formation and development of a full-fledged } \\
\text { tourism cluster in volgograd }\end{array}$ \\
\hline \multirow{2}{*}{ Nur-Sultan } & $\begin{array}{l}\text { Development of an educational cluster as a tool of providing highly qualified personnel and a way to } \\
\text { attract investment }\end{array}$ \\
\hline & $\begin{array}{l}\text { Development of a cluster of financial services to improve their quality, stimulating development of finan- } \\
\text { cial technologies, creating knowledge and technologies transfer }\end{array}$ \\
\hline \multirow[b]{2}{*}{ Almaty } & Development of an international-level tourism cluster \\
\hline & $\begin{array}{l}\text { Creation of scientific-educational-production clusters in conjunction with the coordination training cen- } \\
\text { ters for training, retraining, advanced training and certification of personnel in organizations of technical } \\
\text { and vocational education }\end{array}$ \\
\hline \multirow[t]{2}{*}{ Shymket } & $\begin{array}{l}\text { Development of greenhouse clusters in the peripheral territory as a way of forming an agricultural zone } \\
\text { with intensive technologies }\end{array}$ \\
\hline & Implementation of the concept 'food clusters' with characteristics of the agricultural park \\
\hline
\end{tabular}

\section{Conclusion}

In our research, we presented an algorithm to analyze cluster policies in large cities and demonstrated the results of such analysis by focusing on the cases of Russian and Kazakh cities.

The regulatory legal acts we considered form the basis of cluster policies in Russia and Kazakhstan, describing their priority areas and state support measures. Cluster policies form an important integral part of regional and urban development.

The universal criteria for cluster classification include the year of creation; number of cluster participants; specialization; and the role of the cluster policy indicated in the strategy of socio-economic development of the territory.

According to the proposed algorithm and criteria, clusters located in large Russian and Kazakh 
cities were compared and classified, which led us to the following conclusions:

- the number of clusters in large Russian and

Kazakh cities is increasing annually;

- most such clusters have 11-50 participants;

- in both countries there are clusters of different specialization;
- strategies for socio-economic development serve as the main documents for devising cluster policies of cities

The proposed set of criteria can be further expanded to obtain qualitatively new results and draw conclusions about the efficiency of the processes of cluster formation and operation.

\section{References}

1. Markov L.S., Kurmashev V.B., \& Nizkovskiy A.Yu. (2017). Federal and Regional Cluster Policy of the Russian Federation. Mir ekonomiki i upravleniya = World of Economics and Management, 17(4), 107-121. (In Russ.) doi: 10.25205/2542-0429-2017-17-4-107-121.

2. Kokareva M.S. (2008). Theoretical aspects of clusters formation: essence and classification. Ekonomika regiona = Economy of Region, S4, 136-148. (In Russ.) Retrieved from: https://elibrary.ru/ item.asp? id=11737034.

3. Furre H. (2008). Cluster Policy in Europe - A Brief Summary of Cluster Policies in 31 European Countries. Oxford Research AS, Norway.

4. Brakman, S., \& van Marrewijk, C. (2013). Reflections on cluster policies. Cambridge Journal of Regions, Economy and Society, 6(2), 217-231. doi: 10.1093/cjres/rst001.

5. Corrado, L., Martin, R., \& Weeks, M. (2005). Identifying and Interpreting Regional Convergence Clusters across Europe. The Economic Journal, 115(502), 133-160. doi: 10.1111/j.00130133.2005.00984.x.

6. Kozonogova, E.A., Elokhova, I., Dubrovskaya, J., \& Goncharova N., (2019). Does state cluster policy really promote regional development? The case of Russia. IOP Conference Series Materials Science and Engineering, 497(1), 012044. doi: 10.1088/1757-899x/497/1/012044.

7. Ketels, C. (2013). Recent research on competitiveness and clusters: what are the implications for regional policy? Cambridge Journal of Regions, Economy and Society, 6(2), 269-284. doi: 10.1093/ cjres/rst008.

8. Di Maria, E., \& Costalonga, G. (2004). Internationalization and innovation in CADSES SMEs and clusters: the INDE results. Internationalization processes and virtual cluster promotion in the CADSES area (INDE project final document), 3, 48-70.

9. Kutsenko, E.S., \& Meissner, D. (2013). Key Features of the First Phase of the National Cluster Programme in Russia. Series: Science, Technology and Innovation. WP BRP 11/STI/2013. Retrieved from: https://publications.hse.ru/mirror/pubs/share/folder/mfcuttkkwb/direct/86788676.

10. Naizabekov, A.B., \& Bozhko, L.L. (2018). Future development of cluster initiatives in the Republic of Kazakhstan. Energy Procedia, 147, 654-659. doi: 10.1016/j.egypro.2018.07.085.

11. Nikonova, M.N. (2016). Cluster policy in the Russian Federation: the basic documents, regulations, institutional factors and concepts. Voprosy politologii = Issues of Politology, 4, 229-239. (In Russ.) Retrieved from: https://elibrary.ru/item.asp?id=27633400.

12. Kutsenko, E. (2015). Pilot Innovative Territorial Clusters in Russia: A Sustainable Development Model. Foresight-Russia, 9(1), 32-55. doi: 10.17323/1995-459x.2015.1.32.55.

13. Rodionova, I., Krezhdenko, T., \& Cezary Madry (2018). Cluster policy in the Russian Federation: a case study of industrial clusters. Quaestiones Geographicae, 37(2), 61-75. doi: 10.2478/ quageo-2018-0021.

14. Mitrofanova, I.V., Sheikin, D.A., Ivanov, N.P., \& Trilitskaya, O.Y. (2019). Quality management of cluster institutional development: new trends and the best practices in regions of the world and Russia. International Journal for Quality Research, 13(2), 253-268. doi: 10.24874/IJQR13.02-01.

15. Zemtsov, S.P., Pavlov, P.N., \& Sorokina, A.V. (2016). Specifics of Cluster Policy in Russia. Equilibrium. Quarterly Journal of Economics and Economic Policy, 11(3), 499-536. doi: 10.12775/ EQUIL.2016.023.

16. Kutsenko, E., Islankina, E., \& Abashkin, V. (2017). Evolution of cluster initiatives in Russia: the impacts of policy, life-time, proximity and innovative environment. Foresight, 19(2), 87-120. doi: 10.1108/FS-07-2016-0030. 
17. Delgado, M., Porter, M., \& Stern, S. (2014). Clusters, convergence and economic performance. Research Policy. 43(10), 1785-1799. doi: 10.1016/j.respol.2014.05.007.

18. Beshimbayev, K. (2004). Industrial and territorial clustering as a vehicle for industrial restructuring. In Paper presented at the Regional forum Public-private Co-operation in Industrial Restructuring. Kazakhstan: Organization for Security and Co-operation in Europe. (In Russ.)

19. Kostenko, O.V. (2016). The main directions and priorities of the cluster policy of Russia. Problemy sovremennoi nauki i obrazovaniya, 8, 78-81. (In Russ.) Retrieved from: https://elibrary.ru/ item.asp?id=26001146.

20. Karlsson, Ch. (2008). Handbook of Research on cluster theory. Cornwall: EdwardElgarPublishing. Retrieved from: https://www.e-elgar.com/shop/gbp/handbook-of-research-on-cluster-theory-9781845425166.html.

21. Kolchinskaya, E.E., Limonov, L E., \& Stepanova, E.S. (2018). The role of clusters and cluster policy in the development of Russian regions: problem statement and an approach to assessment. Izvestiya Russkogo geograficheskogo obshchestva = Proceedings of the Russian Geographical Society, 150(3), 1-11. (In Russ.) Retrieved from: https://elibrary.ru/item.asp?id=34915729.

22. Vasilyeva, O.A. (2015). Cluster policy in Kazakhstan: preconditions and peculiarities of cluster agrarian. Gosudarstvennyi sovetnik = The State Counsellor, 2, 16-20. (In Russ.) Retrieved from: https://gossovetnik.files.wordpress.com/2015/07/150203.pdf.

23. Islankina, E.(2015). Internationalization of Regional Clusters: Theoretical and Empirical Issues. Series: Science, Technology and Innovation. WP BRP 41/STI/2015. doi: 10.2139/ssrn.2623532.

24 Kireyeva, A.A., Mussabalina, D. S., \& Tolysbaev, B.S. (2018). Assessment and identification of the possibility for creating clusters in Kazakhstan regions. Ekonomika regiona = Economy of Region, 14(2), 463-473. doi: 10.17059/2018-2-10.

25. Engel, J.S., del-Palacio, I. (2009). Global networks of clusters of innovation: Accelerating the innovation process. Business Horizons, 52(5), 493-503. doi: 10.1016/j.bushor.2009.06.001.

26. Turgel, I.D., Bozhko, L.L., \& Pracheva, E.V. (2019). Special economic zones as a tool for regional and cluster policies (experience of Russia and Kazakhstan). Nauchnye trudy volnogo ekonomicheskogo obshchestva Rossii = Scientific works of the Freedom economic society of Russia, 215(1), 385-400. (In Russ.) Retrieved from: https://elibrary.ru/item.asp?id=38072887.

\section{Information about the authors}

Irina D. Turgel - Doctor of Economics, Professor, Ural Federal University (19 Mira Str., Ekaterinburg, 620002, Russia); e-mail: turgel@k96.ru

Larissa L. Bozhko - Doctor of Economics, Economics and Management Department, Vice-rector on academic affairs and research, Rudny Industrial Institute (50 Let Oktyabrya Str. 38, Rudny, 111500); e-mail: leonlaris@mail.ru

Veronika T. Pandzhiyeva - master student, Ural Federal University, (Mira Street 19, Ekaterinburg, 620002, Russia); e-mail: pandzhieva1667@yandex.ru

ARTICLE INFO: received December 12, 2019; accepted February 5, 2020

\section{Информация об авторах}

Тургель Ирина Дмитриевна - доктор экономических наук, профессор, Уральский федеральный университет (620002, Россия, г. Екатеринбург, ул. Мира, 19); e-mail: turgel@k96.ru

Божко Лариса Леонидовна - доктор экономических наук, доцент, кафедра экономики и менеджмента, проректор по учебной и научной работе, Рудненский индустриальный институт (111500, Казахстан, г. Рудный, ул. 50 лет октября, 38); e-mail: leonlaris@mail.ru

Панджиева Вероника Тимуровна - магистрант Уральского федерального университета (620002, Россия, г. Екатеринбург, ул. Мира, 19); e-mail: pandzhieva1667@yandex.ru

ИНФОРМАЦИЯ О СТАТЬЕ: дата поступления 12 декабря 2019 г.; дата принятия к печати 5 февраля 2020 г. 